\title{
ÖKOLÓGIA ÉS KONVENCIONÁLIS KÖRÜLMÉNYEK KÖZÖTT TERMESZTETT SZAMÓCA (FRAGARIA × ANANASSA) HOZAMA ÉS ANTIOXIDÁNS KAPACITÁSA
}

\section{YIELD AND ANTIOXIDANT CAPACITY OF ORGANICALLY AND CONVENTIONALLY CULTIVATED STRAWBERRY (FRAGARIA $\times$ ANANASSA)}

\author{
Mihálka Virág ${ }^{1 *}$, Székelyhidi Rita ${ }^{2}$, Hanczné Lakatos Erika ${ }^{2}$, Kapcsándi Viktória ${ }^{2}$, Palkovics \\ András ${ }^{3}$, Király Ildikó ${ }^{4}$
}

\footnotetext{
${ }^{1}$ Agrártudományi Tanszék, Kertészeti és Vidékfejlesztési Kar, Neumann János Egyetem, Magyarország 2 Élelmiszertudományi Tanszék, Mezőgazdaság- és Élelmiszertudományi Kar, Széchenyi István Egyetem, Magyarország

${ }^{3}$ Agrárökonómiai és Vidékfejlesztési Tanszék, Kertészeti és Vidékfejlesztési Kar, Neumann János Egyetem, Magyarország

${ }^{4}$ Kertészeti Tanszék, Kertészeti és Vidékfejlesztési Kar, Neumann János Egyetem, Magyarország https://doi.org/10.47833/2020.2.AGR.003
}

\section{Kulcsszavak: \\ szamóca \\ funkcionális élelmiszer \\ ökológiai \\ összes antioxidáns kapacitás \\ összes polifenol mennyiség}

\section{Keywords:}

strawberries

functional food

organically grown

antioxidant capacity

phenolic content

\section{Cikktörténet:}

Beérkezett 2019. szept. 18

Átdolgozva 2020. március 10

Elfogadva 2020. március 15

\begin{abstract}
Összefoglalás
Kísérletsorozatunkban vizsgáljuk a termesztési körülmények hatását szamóca gyümölcsminöségére, különös tekintettel annak antioxidáns illetve polifenol tartalmára. Jelen cikkben a telepítés évében szüretelt gyümölcsök összes antioxidáns és polifenol tartalmát hasonlítottuk össze ökológiai és konvencionális gazdálkodás körülményei közt.

Abstract

In a series of experiments we investigate the effect of growing conditions on the quality of strawberry fruits, especially its antioxidant and polyphenol content. In this article, we compared antioxidant and polyphenol contents of the fruits harvested in the year of planting under the conditions of organic and conventional farming.
\end{abstract}

\section{Bevezetés}

A szamóca kitűnő forrása a rostoknak, vitaminoknak, ásványi anyagoknak, antioxidáns vegyületeknek stb. Az antioxidánsok, és azon belül a polifenol vegyületek igazoltan hozzájárulnak többféle humán betegség ( $\mathrm{pl}$. kardiovaszkuláris betegségek) megelözéséhez. Több kutatási eredmény utal arra, hogy a szamócafogyasztás megelőző jellegü lehet magas vérnyomás, gyulladásos folyamatok, daganatos megbetegedések esetében. A szamócafogyasztás emberi egészségre gyakorolt pozitív hatásainak köszönhetően a szamóca gyümölcse funkcionális élelmiszernek tekinthető [2].

\footnotetext{
* Kapcsolattartó szerző.

E-mail cím: mihalka.virag@kvk.uni-neumann.hu
} 
A nagy mennyiségben alkalmazott mütrágya, a növényvédőszerek, gyomirtók alkalmazása, azok növényben, talajban való jelenléte, illetve bomlástermékeik szervezetünkbe jutása köztudottan káros hatást gyakorolnak egészségünkre. Az emberi egészségre pozitív hatást gyakorló élelmiszer (funkcionális élelmiszer) előállításához az első lépés tehát a kemikáliák alkalmazásának csökkentése. Ezt a célt támogatja az ökológia gazdálkodás termesztéstechnológiája. ÉszakAmerikában és Európában az ökológiai gazdálkodással kapcsolatban a fogyasztók jelentős része pozitív attitüdöt mutat [4] [5]. Általános vélekedés szerint, a bio-termékek fogyasztása egészségesebb. Sokan úgy gondolják, hogy a bioélelmiszerek kevesebb növényvédőszermaradványt tartalmaznak, jobb a gyümölcsök minősége, több ásványianyag és nagyobb vitamintartalom jellemzi a biogyümölcsöket a konvencionális módon elöállítottakkal összevetve. Ugyanakkor kevés, illetve ellentmondásos adatot találunk a szakirodalomban arra vonatkozólag, hogy a biogyümölcsök beltartalmi paraméterei és különösen a bioaktív növényi vegyületek mennyiségei hogyan viszonyulnak a konvencionális gazdálkodásban előállított gyümölcsökéhez viszonyítva [7] [8].

Reganold és munkatársai (2010), 13 ökológiai illetve konvencionális gazdaságban hasonlították össze a gyümölcsök minöségét [9]. A biogyümölcsök esetében szignifikánsan nagyobbnak találták az összes antioxidáns kapacitás, C-vitamin, és összes polifenol mennyiségeket, ugyanakkor az egyes speciális polifenol jellegü vegyületek (kvercetin, ellágsav) mennyiségében nem találtak szignifikáns különbséget [9]. Tõnutare és munkatársai [7] 2-2 gazdaság gyümölcseit hasonlították össze, és Reganold-ékhoz [9] hasonlóan nagyobbnak találták az organikus gazdaságban előállított szamóca összes antioxidáns tartalmát.

Kísérletsorozatunkban ökológiai illetve konvencionális gazdálkodás körülményei között elöállított szamóca hozamát, és gyümölcsösszetételét (makro- és mikroelem, cukor, sav, antioxidáns stb.) hasonlítjuk össze. Amennyiben sikerül az ökológiai gazdálkodás körülményei között a konvencionális gazdálkodásban elért hozamokat megközelíteni, és sikerül bizonyítanunk, hogy ezen gyümölcsök beltartalmi paraméterei (különösen a bioaktív komponensek tekintetében) felülmúlják a konvencionális gyümölcsökét, érdemes lehet elgondolkodni a bio szamóca termelésén, és azt mint funkcionális élelmiszert értékesíteni. Jelen munkában a telepítés évében szüretelt gyümölcsök hozamait, valamint antioxidáns és polifenol tartalmát hasonlítjuk össze.

\section{Anyag és módszer}

\subsection{A kísérlet helyszíne, a telepítés körülményei}

Kísérletünket a Neumann János Egyetem Kertészeti és Vidékfejlesztési Karának Kísérleti kertjében állítottuk be (Kecskemét, Magyarország). Fragaria $\times$ ananassa 'Asia' frigo palántákat 2019. március 26-án telepítettük, ikersoros elrendezésben $(30 \mathrm{~cm}$ sortáv, $25 \mathrm{~cm}$ tőtáv, $60 \mathrm{~cm}$ művelő út). A kijelölt terület egyik végében kialakítottunk egy konvencionális parcellát, míg a terület többi részén az ökológiai gazdálkodás követelményeinek megfelelö körülményeket biztosítottunk. A két területet parlagon hagyott sávval választottuk el.

Az alaptrágyázást és a tápanyagutánpótlást a korábban végzett talajanalízis alapján terveztük meg. Mivel összehasonlító kísérletről van szó, úgy terveztük meg a tápanyagutánpótlást, hogy az alkalmazott szerves illetve mütrágyákból nagyjából azonos mennyiségü nitrogén illetve kálium kerüljön kijuttatásra az ökológia illetve a konvencionális területen. Ennek megfelelöen a konvencionális parcellára összesen $233 \mathrm{~kg} / \mathrm{ha}$ Haifa Turbo és $125 \mathrm{~kg} / \mathrm{ha}$ granulált kálium- szulfátot, míg az ökológiai területre $700 \mathrm{~kg} / \mathrm{ha}$ Phoenix pelletált baromfitrágyát juttattunk ki, így azonos mennyiségű nitrogén és kálium került kijuttatásra. Az öntözést mikroszórófejes öntözörendszerrel végeztük.

A május elején több hétig tartó esőzés miatt, gomba elleni védekezés vált szükségessé. Május 31-én az ökológiai gazdálkodásban engedélyezett réztartalmú Scudo lombtrágya készítmény került kijuttatásra $2 \mathrm{ml} / /$ töménységben, egyszeri alkalommal.

\subsection{Hozamok kiértékelése}

Három ökológiai és az egy konvencionális területröl jelöltünk ki 20-20 növényt egyszerü véletlen mintavétellel. A szüret június 3-án kezdödött. A gyümölcsöket növényenként külön 
gyüjtöttük, számoltuk. Tolómérövel lemértük a gyümölcs hossztengelyére merölegesen mért legnagyobb átmérőt $(\mathrm{mm})$. Az 543/2011 EU rendelet [10] szamócára vonatkozó forgalmazási előírásában található minimális méretre vonatkozó rendelkezése alapján meghatároztuk az extra ( $\min .25 \mathrm{~mm}$ ), ill. összevontan az I. és II. osztályú (min. $18 \mathrm{~mm}$ ) gyümölcsök arányát. Meghatároztuk a növényenkénti kumulatív hozamot, az 1+2. osztályú illetve extra kategóriájú gyümölcsökre vonatkozóan külön-külön, valamint a selejt mennyiségét.

\subsection{Mintaelőkészítés beltartalmi mérésekhez}

A gyümölcsöt szedés után fagyasztottuk. Közvetlenül a mérés elött aprítottuk, majd a felaprított mintából $20 \mathrm{~g}$-ot $70 \mathrm{ml}$ metanolt, $0,1 \mathrm{ml} 37 \%$-os sósavat és $29 \mathrm{ml}$ ionmentes vizet tartalmazó extraháló eleggyel 1 óra hosszát mágneses keverővel kevertettük, majd ezt követően 10 ${ }^{\circ} \mathrm{C}$-on, $5500 \mathrm{~g}$ gyorsuláson 20 percen keresztül centrifugáltuk. Az anitoxidáns és polifenol tartalom meghatározásához az így előállított extraktumot használtuk.

\section{4. Összes antioxidáns kapacitás és összes polifenol-tartalom meghatározása}

Az összes antioxidáns kapacitást Benzie és Strain [3] módosított FRAP módszere alapján határoztuk meg. $100 \mu \mathrm{l}$ térfogatú extraktumhoz $3 \mathrm{ml}$ FRAP oldatot és $100 \mu \mathrm{l}$ nagy tisztaságú vizet adtunk. Gyümölcsöt nem tartalmazó extraktummal szemben, $593 \mathrm{~nm}$-en, spektrofotométerrel mértük.

Az összes polifenol-tartalom meghatározása során $100 \mu \mathrm{l}$ térfogatú extraktumhoz 1,5 ml nagy tisztaságú vizet adunk, majd hozzá adjuk a reagenseket. Először 2,5 ml Folin reagenst, majd $2 \mathrm{ml}$ $\mathrm{Na}_{2} \mathrm{CO}_{3}$-ot. $\mathrm{Az}$ abszorbanciát 90 perc elteltével $750 \mathrm{~nm}$-en, gyümölcsöt nem tartalmazó extraktummal szemben, spektrofotométerrel mértük.

A spektrofotométerünk kalibrációja során készített 40,60, 80, 100, 150, 200, 250, és 500 mg/l koncentrációjú, antioxidáns kapacitás vizsgálat során aszkorbinsav, míg összes polifenol tartalom meghatározás során galluszsav mérőoldatokkal hasonlóképpen járunk el. A szamócaminták összes antioxidáns és összes polifenol tartalmát a mérőoldatokra mért abszorbancia és a hozzájuk tartozó koncentráció értékpárokra a nemlineáris legkisebb négyzetek módszerével illesztett másodfokú analitikai mérögörbe egyenletének felhasználásával szamóca mintaoldatokra mért abszorbancia értékekből határozzuk meg.

Az alábbi képlet segítségével határozzuk meg a szamóca összes antioxidáns és összes polifenol koncentrációját.

$$
\mathrm{c}=\frac{100 * \mathrm{~A}}{a * m}
$$

ahol:

c: az adott alkotó koncentrációja

A: az adott alkotó abszorbanciája

$\mathrm{V}$ : a mintaoldat higítási térfogata $(100 \mathrm{~mL})$

$\mathrm{m}$ : a bemért szamóca tömege

a: analitikai mérögörbe meredeksége

\subsection{Statisztikai kiértékelés}

Mivel a Leven-féle szignifikancia tesztet alkalmazva több vizsgált paraméter esetében nem teljesült a szórások homogenitása, ezért ANOVA helyett független mintás T-próbával vizsgáltuk meg, hogy a kezelés hatására szignifikáns különbséget okozott-e a gyümölcsméretekben illetve hozamokban.

\section{Eredmények és értékelés}

A szüret - viszonylag későn -, június 3-án indult, ami a szüreti időszakot megelőző esős, és napsütésben szegény időjárásnak volt betudható. Három ökológiai illetve egy konvencionális parcellán 20-20 növény kumulatív hozamát összehasonlítva azt tapasztaltuk, hogy az egyes ökológiai parcellák között jelentősebb hozambeli különbségek voltak mérhetők, mint az ökológiai és konvencionális parcellák között (1. ábra). Ezt a statisztikai vizsgálatok is megerősítették. A 
kiértékelésnél figyelembe kell vennünk, hogy frigo palánták esetében a telepítés évében nem várunk magas hozamokat. A kapott értékek (38- $66 \mathrm{~g} / \mathrm{tő}$ átlagos hozamok a piacképes gyümölcsökre vonatkozóan) hasonlóak a 2017-es telepítésünk telepítés évi hozamaihoz, melyek 35- $45 \mathrm{~g} /$ tö körüliek voltak [6].

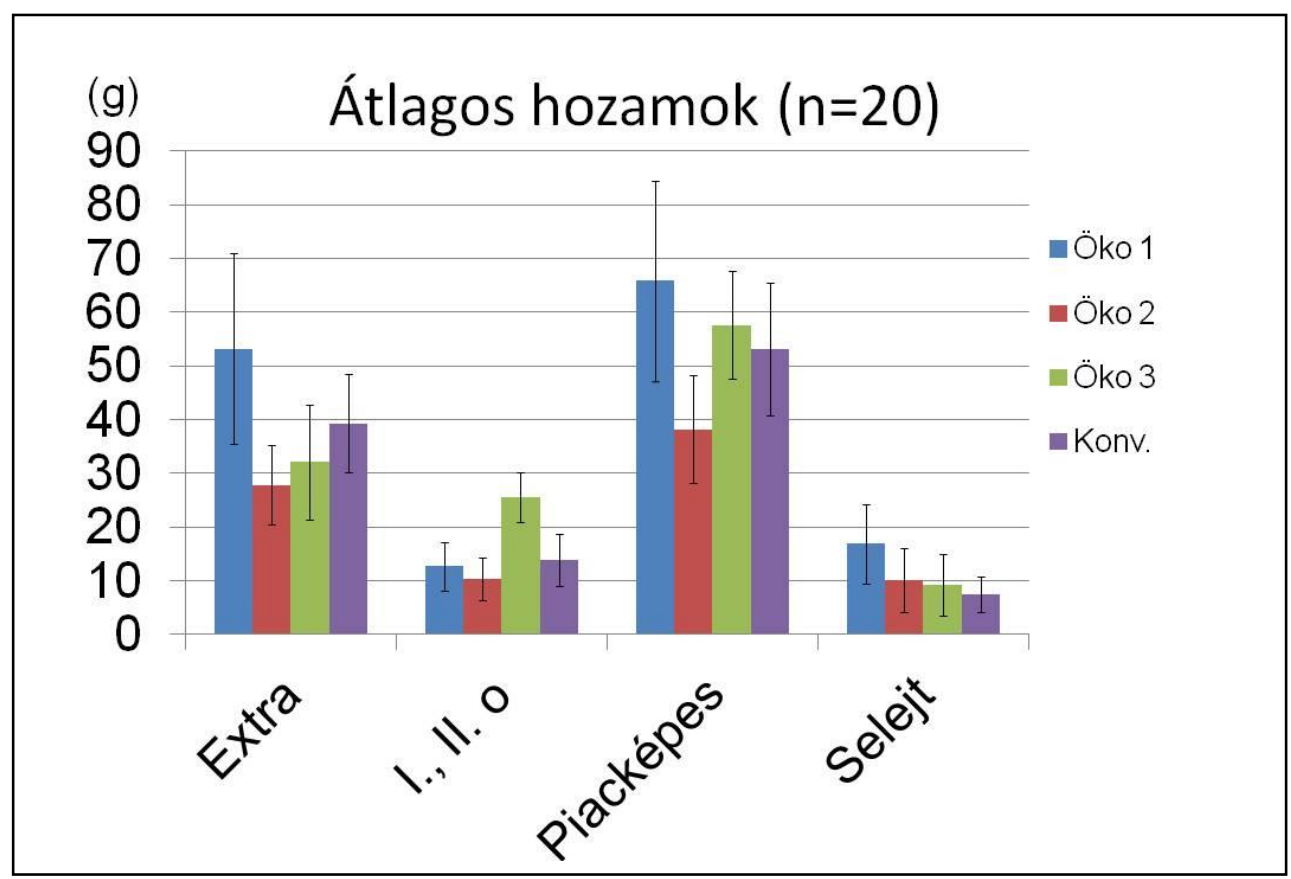

1. ábra. Növényenkénti átlagos hozamok. Három ökológiai és egy konvencionális parcellán 20-20 növény átlagos hozama, szórásokkal.

A 2019-es évben a szamócatermesztők körében nagy problémákat okozott az érési időszakot megelőző hirtelen érkező nagy mennyiségü csapadék, - mely gyakorisága miatt a permetezést is lehetetlenné tette -, illetve a napfény hiánya. Az állandó nedvesség kedvezett a gombás megbetegedések jelentkezésének. Ültetvényünkön Phytophthora és Colletotrichum fragariae tünetei jelentkeztek, amik jelentős mértékü tőpusztulást és átlagosan $16-32 \%$ között hozamveszteséget idéztek elö (2. ábra), valamint a gyümölcsök minőségének romlását eredményezték.

A gombás tünetek visszaszorítása céljából réztartalmú Scudo lombtrágyát permeteztünk ki, de ez nem javított jelentősen a helyzeten. 2019-ben erősen befolyásolta tehát a piacképes gyümölcsök mennyiségét, a jelentős mértékü veszteség. Elmondható, hogy nem találtunk szignifikáns különbséget az ökológiai és konvencionális tápanyag-utánpótlást kapott szamóca parcellák hozamai között. Jelentős különbségek voltak ugyanakkor egyes ökológia területek között.

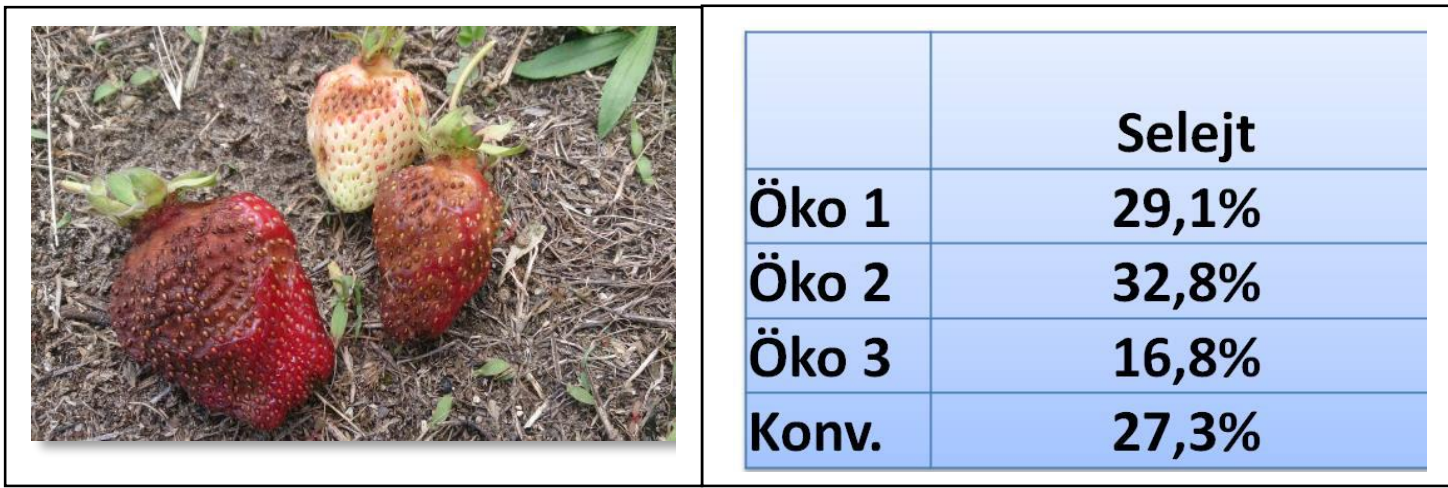

2. ábra. Phytophtora és Colletotrichum tünetek és a selejt aránya 
Szintén nem találtunk jelentős különbséget az extra méretü gyümölcsök arányában az ökológiai és a konvencionális gyümölcsök között. Átlagosan 55 és $80 \%$ közötti volt a piacképes gyümölcsök \%-ában az extra méretü gyümölcsök aránya. Meg kell azonban jegyeznünk, hogy a mért hozamok jelentős mértékben szóródtak (1. ábra), ami a statisztikai kiértékelés eredményét bizonytalanná teszi.

Az összes antioxidáns és összes polifenol tartalom mérés eredményeit a 3. sz. ábrán mutatjuk be. Az oszlopdigramon 3-3 mérés átlagát tüntettük fel.

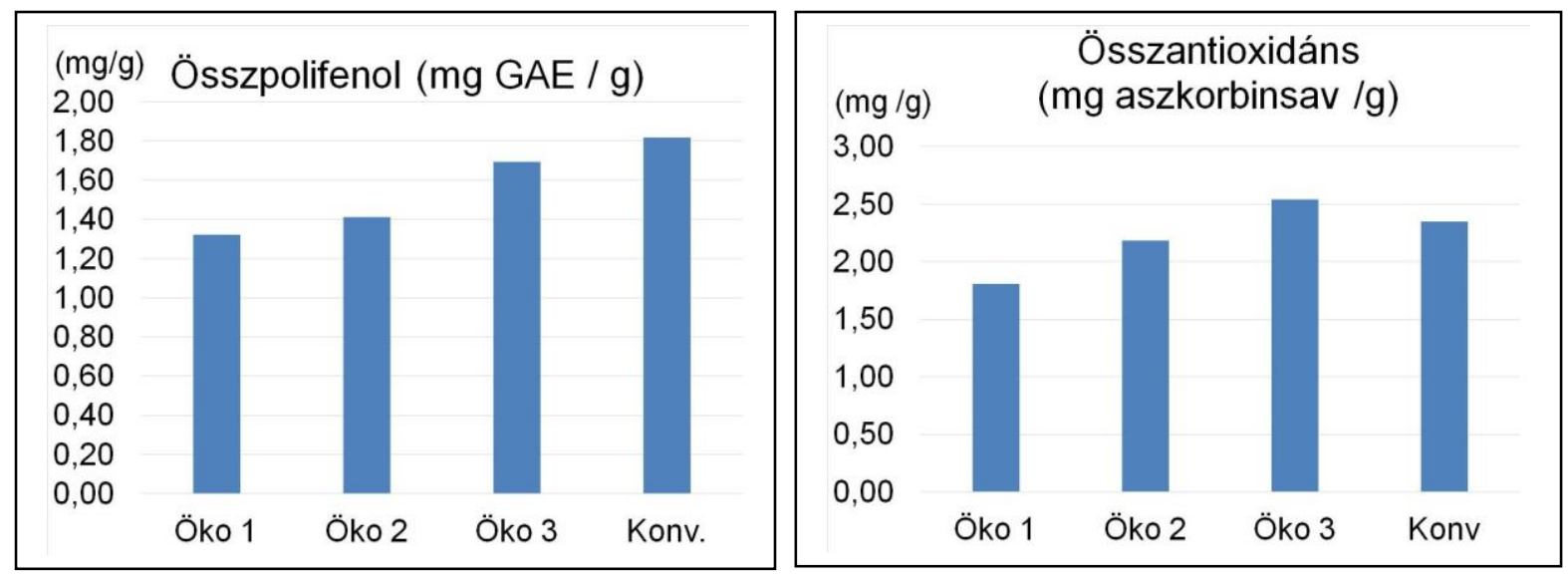

3. ábra. Összes polifenol és antioxidáns tartalom $(n=3)$

A telepítés évében nem találtunk jelentős különbséget az ökológia és konvencionális körülmények között termesztett szamóca összes antioxidáns kapacitásban.

A galluszsav egyenértékben megadott polifenol tartalomban szintén nem találtunk szignifikáns különbséget.

\section{Következtetések}

Jelen munkában a telepítés évében kapott eredményeket értékeltük. Ezek alapján nem bizonyítható, hogy az ökológiai és konvencionális gyümölcsök összes antioxidáns illetve polifenol tartalma között különbség lenne. A hozamokban szintén nem tapasztaltunk egyértelmü különbséget. $\mathrm{Az}$ eredmények interpretálása során figyelembe kell vennünk, hogy a frigo palánták esetében a telepítés éve nulladik évnek tekinthető, ezt az alacsony hozamok miatt általában nem értékesítik a termelök, csak növényvédelmi okok miatt szedik le a gyümölcsöket. Továbbá azt is, hogy az ökológiai és konvencionális gazdálkodás körülményei között termelt gyümölcsökben mért beltartalmi különbségek [7] [9] több éves biogazdálkodás következményként jelentkeznek, a területen kialakult egészséges ökoszisztémáknak, illetve talaj mikrobiomnak is köszönhetően. Várhatóan a következő években jobban megmutatkoznak majd az esetleges különbségek.

\section{Köszönetnyilvánítás}

Köszönettel tartozunk a kutatás támogatásáért, amely az EFOP-3.6.2-16-2017-00012 „Funkcionális, egészséges és biztonságos élelmiszer termékpálya modell kidolgozása a szántóföldtől az asztalig elv alapján, tematikus kutatási hálózatban" pályázat keretében valósult meg.

A projekt a Magyar Állam és az Európai Unió támogatásával, az Európai Szociális Alap társfinanszírozásával, a Széchenyi 2020 program keretében valósul meg.

A szerzők köszönetet mondanak továbbá Ágoston Jánosnak a kórokozók azonosításában nyújtott segítségéért. 


\section{Irodalomjegyzék}

[1] Asami, D.K, Hong Y. J., Barrett, D.M. \& Mitchell, A.E. (2003): Comparison of the total phenolic and ascorbic acid content of freeze dried Marion berry, strawberry and corn using conventional, organic and sustainable agriculture practises. Journal of Agricultural and Food Chemistry 51, 1237-1241.

[2] Basu, A., Nguyen, A., Betts, N. M., \& Lyons, T. J. (2014): Strawberry as a functional food: an evidence-based review. Critical reviews in food science and nutrition, 54(6), 790-806.

[3] Benzie, I. F., \& Strain, J. J. (1996): The ferric reducing ability of plasma (FRAP) as a measure of "antioxidant power": the FRAP assay. Analytical biochemistry, 239(1), 70-76.

[4] Loureiro, M., Mccluskey, J., Mittelhammer, R. (2001): Assessing Consumer Preferences for Organic, Eco-labeled, and Regular Apples. Journal of Agricultural and Resource Economics. 26.

[5] Magnusson, M. , Arvola, A. , Hursti, U., Åberg, L., Sjödén, P. (2001): Attitudes towards organic foods among Swedish consumers. British Food Journal. 103. 209-227.

[6] Mihálka Virág, Gyurkó Adrienn, Ferencz Árpád, Király lldikó (2019): Mikroalga és baktériumkészítmények kombinált alkalmazásának hatása szamóca (Fragaria ananassa cv. Joly) terméshozamára. In: Kőszegi, Irén Rita (szerk.) III. Gazdálkodás és Menedzsment Tudományos Konferencia: Versenyképesség és innováció. Kecskemét, Magyarország: Neumann János Egyetem, pp. 845-850. , 6 p

[7] Tõnutare, T., Moor, U., Mölder, K., Põldma, P. (2009): Fruit composition of organically and conventionally cultivated strawberry 'Polka'.

[8] Törrönen, R., Määttä, K. (2000): Bioactive substances and health benefits of strawberries. In IV International Strawberry Symposium 567 (pp. 797-803). DOI:10.17660/ActaHortic.2002.567.176

[9] Reganold JP, Andrews PK, Reeve JR, Carpenter-Boggs L, Schadt CW, et al. (2010): Fruit and Soil Quality of Organic and Conventional Strawberry Agroecosystems. PLOS ONE 5(9): e12346. https://doi.org/10.1371/journal.pone.0012346

[10] 543/2011 EU rendelet. A bizottság 543/2011/EU végrehajtási rendelete (2011. június 7.) az 1234/2007/EK tanácsi rendeletnek a gyümölcs- és zöldség-, valamint a feldolgozott gyümölcs- és feldolgozott zöldség-ágazatra alkalmazandó részletes szabályainak a megállapításáról. content/HU/TXT/PDF/?uri=CELEX:32011R0543\&qid=1473169898407\&from=HU 